\title{
DEBUTS
}

Stella Sarapani ${ }^{*}$

Styliani.Sarapani@uantwerpen.be

orcid.org/0000-0002-8185-4117

Prinsstraat 13

Antwerp 2000

Belgium

\section{The Import of Cultural Goods under EU and Greek Law - A Critical Outlook}

\begin{abstract}
In recent decades, there have been many offences against world cultural heritage by terrorist entities aimed not only at damaging the historical past and cultural identity of specific nations, but also at financing their activities through the sale of cultural objects. The European Union (EU) countries have often been the recipients of such cultural goods from conflict-ridden territories. For this reason, the EU has gradually adopted a set of legal measures aimed at reducing the flow of illegal cultural goods from third countries into its territory. Focusing on the North-Eastern Mediterranean boundaries of the EU for geopolitical reasons, this article examines the EU's legal measures regarding the import of cultural goods from third countries from the perspective of Greece in order to investigate whether the new regulatory measures could be effective in this particular Member State. On one hand this article examines EU Regulation No. 1210/2003, Regulation No. 1332/2013, and Regulation No. 2019/880; and on the other it analyses Article 33 of the Greek Law 3028/2002 regarding the import of cultural goods. As regards the latter, this approach includes not only the law itself
\end{abstract}

\footnotetext{
* Stella Sarapani is a PhD student at the Faculty of Law at the University of Antwerp (Belgium). She holds a Master's degree in Art Law and Economy from the International Hellenic University of Thessaloniki (Greece) and a Bachelor of Honours in Classics from the Aristotle University of Thessaloniki (Greece). Her research focuses on the illicit trafficking of antiquities in South-East Europe.
} 


\section{DEBUTS}

Stella Sarapani

but also cases generated under it, its legislative history where applicable, and commentaries and literature on the law that will enable the measurement of the effectiveness of the new measures in Greece. Comparisons are also made herein, albeit to a lesser extent and mainly between the EU import rules and the relevant national rules, as the effects of EU law upon Greek law are yet to be identified.

Keywords: import, EU, Greece, Regulation (EU) 2019/880, "last country"

\section{Introduction}

On 27 June 2019, Regulation (EU) 2019/880 on the introduction and the import of cultural goods ${ }^{1}$ ("new Regulation") entered into force. This new Regulation, which is part of a broader plan to combat terrorism financing, introduces common rules regarding trade in cultural property with third countries. In recent years, the destruction of archaeological sites and illicit excavations in turbulent parts of the Middle East and of the world, such as Syria, Iraq, and Afghanistan, and the connection of these activities with the financing of terrorism have shocked the global community. The destruction of Palmyra in Syria by ISIS, the destruction of the Bamiyan Buddhas in Afghanistan by the Taliban, and the looting of the Iraqi National Museum in Baghdad in 2003 are some of the most notable examples. ${ }^{2}$ These instances, in combination with increasingly frequent seizures of illegally imported cultural goods in the EU (i.e. French Customs' 2016 seizure in Roissy) ${ }^{3}$ and the Schengen Area (the 2016 seizures by Swiss Authorities in Geneva Free Port $)^{4}$ have led to recognition of the urgent necessity for new legal measures at the EU level to tackle the phenomenon.

1 Regulation (EU) 2019/880 of the European Parliament and of the Council of 17 April 2019 on the introduction and the import of cultural goods, OJ L 151, 7.06.2019, p. 1.

2 For instance, see C. Dempsey, Mapping the Destruction of UNESCO World Heritage Sites, "Geography Realm", 25 January 2016, https://www.geographyrealm.com/mapping-the-destruction-of-unescoworld-heritage-sites/ [accessed: 24.09.2021].

3 N. Revenu, Un Trésor Archéologique Saisi à Roissy, "Le Parisien", 21 September 2016, https://www.leparisien.fr/faits-divers/un-tresor-archeologique-saisi-a-roissy-21-09-2016-6136959.php [accessed: 26.09.2021].

4 Looted antiquities from Palmyra in Syria, Yemen, and Libya have been confiscated in the Geneva Free Port in 2016, see H. McGivern, Palmyra Antiquities Seized at Geneva Free Port, "The Art Newspaper", 5 December 2016, https://www.theartnewspaper.com/news/palmyra-antiquities-seized-at-geneva-free-port [accessed: 26.09.2021]. 
Before the adoption of new legal measures in 2019, the only legislation in force at the EU level controlling the import of cultural goods from third countries was Council Regulation (EC) No. $1210 / 2003^{5}$ on restrictions on trade with Iraq, and Council Regulation (EU) No. 1332/20136 on restrictions on trade with Syria. The EU legal framework for the control of trade in cultural goods - which until 2019 only included legal measures for the export of cultural goods (Council Regulation (EC) No. 116/2009); ; for the return of goods unlawfully removed from their country of origin (Directive 2014/60/EU); 8 and the above-mentioned trade restrictions on Iraq and Syria - has been reinforced as a whole and also expanded by the new Regulation. In this sense, it could be argued that the new Regulation has prima facie created an appropriate uniform regime in the customs territory for the control of trade in cultural goods.

This article offers a closer look at the new regulatory measures, with special focus on their impact on Greece's legal framework. The choice of Greece is not random. The geographical position of Greece and its proximity to the Middle East make it a very interesting case for exploring the interaction between EU law and national law. To this end, this article first focuses on the EU's initial legal approach in relation to the import of non-EU cultural goods, and specifically on the ad hoc measures taken for Iraq and Syria. Secondly, it examines the new EU legal approach to the issue by analysing Regulation (EU) 2019/880. The third part of this article uses the case of Greece to examine the way this Member State deals with the import of non-EU cultural goods in its territory in view of the new Regulation. The article concludes with a set of critical remarks.

\section{The EU's First Legal Approach:}

\section{The Ad Hoc Measures on Iraq and Syria}

In 2003, the EU adopted Regulation No. 1210/2003, by which it imposed various restrictions on Iraq, including restrictions on the import of cultural goods into the Union's territory. Article 3 restricts trade in cultural goods by prohibiting any movement of Iraqi cultural property or other items of archaeological, historical, cultural, rare scientific, and religious importance.

\footnotetext{
5 Council Regulation (EC) No. 1210/2003 of 7 July 2003 concerning certain specific restrictions on economic and financial relations with Iraq and repealing Regulation (EC) No. 2465/96, OJ L 169, 8.07.2003, p. 6.

6 Council Regulation (EU) No. 1332/2013 of 13 December 2013 amending Regulation (EU) No. 36/2012 concerning restrictive measures in view of the situation in Syria, OJ L 335, 14.12.2013, p. 3.

7 Council Regulation (EC) No. 116/2009 of 18 December 2008 on the export of cultural goods (Codified version), OJ L 39, 10.02.2009, p. 1.

8 Directive 2014/60/EU of the European Parliament and of the Council of 15 May 2014 on the return of cultural objects unlawfully removed from the territory of a Member State and amending Regulation (EU) No. 1024/2012 (Recast), OJ L 159, 28.05.2014, p. 1.
} 


\section{DEBUTS}

Stella Sarapani

Ten years later, in 2013, the EU adopted Regulation No. 1332/2013 in view of the situation in Syria. It imposes, inter alia, restrictions on trade in cultural goods. These restrictions concern the prohibition of import, export, transfer, or negotiations related to the import, export, or transfer of Syrian cultural property goods and other goods having archaeological, historical, cultural, rare scientific, or religious significance, especially where there are reasonable grounds to suspect that the goods have been removed from the territory of Syria without the consent of their rightful owner or have been removed in violation of Syrian law or international law. ${ }^{9}$

These ad hoc measures for Syria and Iraq were the EU's first legal approach with regard to the importation of third country goods into the EU customs territory $y^{10}$ and were the result of calls from the United Nations, as expressed in Resolution 1483 of $2003^{11}$ and Resolution 2199 of $2015^{12}$ for Iraq and Syria respectively.

Yet, the effectiveness and adequacy of these ad hoc measures have been questioned, as reflected in the European Commission's 2017 report on "fighting illicit trafficking in cultural goods", where it concluded they had led only exceptionally to the identification of illicitly imported cultural goods from Syria and Iraq into the customs territory, while there were still reasonable suspicions from several cases in the Member States that Syrian and Iraqi cultural goods continued to enter the customs territory illegally. ${ }^{13}$ As stated above, in 2016 French Customs seized various archaeological artefacts from Syria and other countries of the Middle East in Roissy Airport. In Germany, the criminal police had seized, back in 2008, a set of Iraqi cultural goods planned to be taken out from the country's borders.$^{14}$ The case of Greece is also interesting and indicative of the situation described in the 2017 report. In the operation "Athina", undertaken by the Greek Customs Service in 2016 under Regulations No. 1210/2003 and No. 1332/2013 to detect illegal cultural goods from Syria, Iraq, Libya, and Lebanon, the number of confiscated cultural goods was near zero out of the 1,562 seizures carried out by the Greek Customs

9 Regulation No. 1332/2013, Article 11c; R. Mackenzie-Gray Scott, The European Union's Approach to Trade Restrictions on Cultural Property: A Trendsetter for the Protection of Cultural Property in Other Regions?, "Santander Art and Culture Law Review" 2016, Vol. 2, pp. 218-220.

10 European Commission, Fighting Illicit Trafficking in Cultural Goods: Analysis of Customs Issues in the EU. Final Report, June 2017, p. 98, https://op.europa.eu/en/publication-detail/-/publication/fadd3791-aa4011e7-837e-01aa75ed71a1/language-en [accessed: 11.10.2021].

11 United Nations Security Council, Resolution 1483: The Situation between Iraq and Kuwait, 22 May 2003, S/RES/1483 (2003).

12 United Nations Security Council, Resolution 2199: Threats to International Peace and Security Caused by Terrorist Acts, 12 February 2015, S/RES/2199 (2015).

13 European Commission, Fighting Illicit Trafficking..., pp. 100-101, 103-104. 
Service that year in a series of other operations. ${ }^{15}$ Yet, despite the small number of identified cases of non-EU cultural goods in the Greek territory, the use of Greece as a "path" for cultural goods from the war zones of Syria and Iraq was a real fact at that time, and it was stated that: "Greece is being used as a passage to export illicit antiquities from Syria and Iraq into the European and American art markets". ${ }^{16}$ Unfortunately, the data available to further strengthen this argument is minimal to non-existent, but there are reports of objects being transported along similar routes by which migrants were making their way to Europe. ${ }^{17}$ Thus, if one associates the movement of cultural goods from third countries with the movement of refugees from the very same countries, i.e. Syria, Iraq, Afghanistan, and Pakistan into Greece at a time when Europe's refugee crisis was at its peak, and also the fact that Greece as a Member State on the doorstep of the EU was recipient of more than 1 million refugees, ${ }^{18}$ then there is a high possibility that Greece was indeed used as a passage for cultural goods from third countries, despite the lack of available data to support this view. In other words, if the routes have coincided (as was the case with the causes that led to these (re)movements, i.e. states of war and terrorism), then Greece could have served as a "path" for cultural goods from the Middle East despite the small number of confiscated artefacts from this area. This incompatibility, so to speak, between what was in the foreground and what was actually happening in the background seems to have stemmed from the practical difficulties in the application of the two Regulations, and in particular the lack of resources available to establish provenance, age, and legitimate owner, as well as the time required for this entire task. ${ }^{19}$ Moreover, the establishment of origin, and hence the effectiveness of the restrictive measures for Iraq and Syria, seems to have been affected by the fact that the importer of a cultural good was able to claim that it originated from another neighbouring State to circumvent the two Regulations. ${ }^{20}$ According to Dr Neil Brodie (University of Glasgow), the EU and UN

15 Directorate for Strategic Planning, Report of the General Secretariat of Public Revenue (GSPR) for the Year 2016 and Planning of Activities of the Independent Authority for Public Revenue (IAPR), March 2017, p. 77, https://www.aade.gr/sites/default/files/2017-06/apologistiki_ekthesi_2016.pdf [accessed: 11.10.2021] (in Greek).

16 Greece a Transit Country for Trade in Illicit Antiquities from Syria, Iraq, "Kathimerini", 24 January 2016, https://www.ekathimerini.com/news/205358/greece-a-transit-country-for-trade-in-illicit-antiquitiesfrom-syria-iraq/ [accessed: 02.07.2021].

17 For instance, see C.A. Weirich, Antiquities in a Time of Conflict: A Crime Script Analysis of Antiquities Trafficking during the Syrian Civil War and Implications for Conflict Antiquities, "Crime Science" 2021, Vol. 10, p. 7.

18 Y. Sakellis, N. Spyropoulou, D. Ziomas, The Refugee Crisis in Greece in the Aftermath of the 20 March 2016 EU-Turkey Agreement, ESPN Flash Report 2016/64, August 2016, p. 1, https://www.europeansources. info/record/the-refugee-crisis-in-greece-in-the-aftermath-of-the-20-march-2016-eu-turkey-agreement/ [accessed: 11.10.2021].

19 European Commission, Fighting Illicit Trafficking..., p. 104.

20 A.-M. Carstens, E. Varner, Intersections in International Cultural Heritage Law, Oxford University Press, Oxford-New York 2020, p. 382. 


\section{DEBUTS}

Stella Sarapani

system of trade controls aimed only at Syrian and Iraqi cultural goods were leaving wide open the opportunity for such goods to be sold and collected with impunity by claiming them as having originated in Turkey, Jordan, Lebanon, or another country in the region. As he notes, the case of Amman resident Ghassan Rihani, who was able to ignore United Nations Security Council (UNSC) Resolution 661 of 199021 by claiming a Jordanian origin for material he was trading from Iraq, precisely illustrates the cracks in these systems. ${ }^{22}$

\section{The New EU Legal Approach: Regulation (EU) 2019/880}

\section{Background}

Aside from the two targeted measures for Syria and Iraq, the EU did not have common rules for the import of cultural goods from third countries. The Member States were applying their own national legislation, where applicable, to regulate the imports of cultural goods. ${ }^{23}$ Not surprisingly, the lack of harmonization in this specific area most likely reinforced, as one might expect, the development of trafficking routes and left Member States vulnerable to illicit trade practices, especially those Member States in geographical proximity to the Middle East. ${ }^{24}$

Having this gap in mind, and with the aim of combating the illicit trafficking of cultural goods from non-EU countries more effectively and systematically, the EU Commission submitted on 13 July 2017 a legislative proposal for a regulation on the import of cultural goods ("Proposal"). ${ }^{25}$ It was prepared within the framework of the 2015 European Agenda on Security ${ }^{26}$ and the 2016 Action Plan to step up the fight against the financing of terrorism. ${ }^{27}$ With this initiative, the EU responded to a number of calls, such as the European Parliament's Resolution on

21 United Nations Security Council, Resolution 661 (1990): Concerning the Situation between Iraq and Kuwait, 6 August 1990, S/RES/661 (1990).

22 N. Brodie, Syria and its Regional Neighbours: A Case of Cultural Property Protection Policy Failure?, "International Journal of Cultural Property" 2015, Vol. 22(2-3), p. 323.

23 European Parliament, Briefing: Regulating Imports of Cultural Goods, EPRS, 28 June 2019, pp. 2-3.

24 European Commission, Questions and Answers on the Illegal Import of Cultural Goods Used to Finance Terrorism, 13 July 2017, https://ec.europa.eu/commission/presscorner/detail/en/MEMO_17_1954 [accessed: 11.10.2021].

25 European Commission, Proposal for a Regulation of the European Parliament and of the Council on the Import of Cultural Goods, 13 July 2017, COM(2017) 375 final.

26 European Commission, Communication from the Commission to the European Parliament, the Council, the European Economic and Social Committee and the Committee of the Regions: The European Agenda on Security, 28 April 2015, COM(2015) 185 final.

27 European Commission, Communication from the Commission to the European Parliament and the Council on an Action Plan for Strengthening the Fight Against Terrorist Financing, 2 February 2016, COM(2016) 50 final. 
the destruction of cultural sites perpetrated by ISIS/Da'esh, ${ }^{28}$ the G20 Leaders call for action of July 2017, ${ }^{29}$ and the G7 Leaders' Statement on the Fight Against Terrorism and Violent Extremism of March 2017, ${ }^{30}$ which followed the important UNSC Resolution 2347 on the protection of cultural heritage at risk of 24 March 2017. ${ }^{11}$ The Proposal underlines the twofold significance, i.e. both national and international, of protecting cultural heritage. Specifically, the proposed new import rules acknowledge the significance of cultural goods to the national heritage, as well as their artistic, historical, and archaeological value to their country of origin, but at the same time they did not fail to emphasize the negative effects of illicit trade in the international art market, such as money laundering, tax evasion, and terrorism financing. According to the European Commission, the new regulatory measures could prevent the import and storage in the EU of cultural goods exported illegally from a third country, thus combating terrorism financing and ultimately protecting cultural heritage. The legislative process was finalized in April 2019, and Regulation (EU) 2019/880 entered into force on 27 June 2019.

\section{The features of the new Regulation}

The new Regulation introduces a system that regulates the import of cultural goods into the EU customs territory. Specifically, the new Regulation ensures that the imports of cultural goods are subject to uniform controls upon their entry into the customs territory of the Union, prevents illegally exported cultural goods from entering the EU, and restricts the circulation of such objects in the Single European Market (SEM). It is also directed against organized crime, especially "where trafficking of cultural goods becomes a source of terrorist financing". ${ }^{2}$

The new Regulation applies only to cultural goods which were created or discovered outside the Union's territory. This means that it does not apply to cultural

28 European Parliament, Joint Motion for a Resolution on the Destruction of Cultural Sites Perpetrated by ISIS/ Da'esh, 28 April 2015, 2015/2649(RSP), https://www.europarl.europa.eu/doceo/document/RC-8-20150375_EN.html?redirect [accessed: 11.10.2021].

29 In July 2017, the G20 Leaders called for countries to "address all alternative sources of financing of terrorism, including dismantling connections, where they exist, between terrorism and transnational organized crime, such as [...] looting and smuggling of antiquities", see European Commission, G20 Leaders' Statement on Countering Terrorism, 7 July 2017, https://ec.europa.eu/commission/presscorner/detail/en/STATEMENT_17_1955 [accessed: 11.10.2021].

30 In March 2017, the G7 Leaders committed to cooperate in protecting cultural heritage and countering of looting and trafficking of cultural goods, acknowledging that such illegal activities constitute a form of terrorism financing, see G7 Taormina Statement on the Fight Against Terrorism and Violent Extremism, http://www.g7italy.it/sites/default/files/documents/G7\%20Taormina\%20Statement\%20on\%20the\%20 Fight\%20Against\%20Terrorism\%20and\%20Violent\%20Extremism/index.pdf [accessed: 11.10.2021].

31 United Nations Security Council, Resolution 2347: Maintenance of International Peace and Security, 24 March 2017, S/RES/2347 (2017).

32 Regulation (EU) 2019/880, Article 1. 


\section{DEBUTS}

Stella Sarapani

goods that constitute part of a Member State's cultural property and, by extension, it does not apply to the (re)import of such goods. The new Regulation thus does not cover the (re)import of a cultural good into the Union's territory that was illegally excavated, say for example in Bulgaria, and then illegally exported to Canada. It concerns exclusively non-EU cultural goods. It should be noted here that, unlike the ad hoc measures for Syria and Iraq, the new Regulation applies to all third countries that are a source of illicit trade in cultural goods. The geographical coverage has thus obviously expanded.

Any cultural good which was removed from its country of origin in breach of the national laws and regulations of that country shall be prohibited from entering the Union's territory (Article 3(1)), and any such attempt shall be penalized under this Regulation (Article 11). The Member States have the discretion to decide on the penalties applicable to those infringements, which in turn means that the penalties may vary from Member State to Member State. At this point, it is clear that under the new Regulation the illegal export of cultural goods implies the illegal import of them into another country. In other words, for the new Regulation the rule is "ratio 1:1" in this type of illicit trade.

The new Regulation introduces the use of an import licence (Article 4) and importer statement (Article 5) for the categories of cultural goods listed in the Annex to the Regulation. According to Article 4(1), an import licence is required for those cultural goods deemed most at risk, i.e. archaeological finds and items removed from monuments and sites, being more than 250 years old, without any financial threshold (Annex, Part B). The cultural goods listed in Part C of the Annex require an importer statement (Article 5(1)) if they exceed 200 years in age with a minimum financial threshold of $€ 18,000$. This automatically creates two categories of cultural goods for which import documentation is required before entry into the EU: a) high-risk cultural goods; and b) lower-risk cultural goods. The rationale behind this different treatment in the scrutiny of non-EU cultural goods is based on the increased risk of pillage of certain categories of cultural goods, such as archaeological finds or parts of monuments which, by their nature, are directly exposed to loss or dispersal. ${ }^{33}$ These are also the very cultural goods that are targeted by terrorists and other warring factions for the purposes of financing their activities, and are also known as "blood-antiquities". ${ }^{34}$ According to the European Commission, this option was deemed proportional to the objectives set, as it organizes import certification requirements in line with the relative risks. ${ }^{35}$

33 European Commission, Proposal..., p. 7.

34 M. John, 'Blood Antiquities': A Wound the World Struggles to Staunch, "Reuters", 10 June 2015, https:// www.reuters.com/article/us-mideast-crisis-antiquities-analysis-idUSKBN0OQ16320150610 [accessed: 11.10.2021].

35 European Commission, Proposal..., p. 5. 
Under Article 4(4) of Regulation (EU) 2019/880 the application for an import licence:

shall be accompanied by any supporting documents and information providing evidence that the cultural goods in question have been exported from the country where they were created or discovered in accordance with the laws and regulations of that country or providing evidence of the absence of such laws and regulations at the time they were taken out of its territory. ${ }^{36}$

As regards the importer statement, such a statement has to consist of a signed declaration "stating that the cultural goods have been exported from the country where they were created or discovered in accordance with the laws and regulations of that country at the time they were taken out of its territory and a document describing the cultural goods in sufficient detail". ${ }^{37}$

It becomes clear from these provisions that the new Regulation attaches great importance to proof of the fact that the holder of an object legally possesses that object and bears title deed in order to request its import into the EU. In other words, the new Regulation puts "pressure" on the holder of an object to be diligent enough so as to prove that the export of that object was made legally from the country of origin, and that any right to it was legally acquired and was not in derogation of the national law of that country. This was, in fact, one of the measures proposed by the European Commission in order to achieve the objectives of this Regulation. ${ }^{38}$ Arguably, this legal obligation is in full compliance with the standards of "due care", as required by Article 10 of Directive 2014/60/EU and international law. Moreover, it corresponds with the standard of "due diligence" as provided in Article 4 of the 1995 UNIDROIT Convention on Stolen or Illegally Exported Cultural Objects ${ }^{39}$ ("1995 UNIDROIT Convention"). Although Regulation (EU) 2019/880 is not as direct as the 1995 UNIDROIT Convention with regard to due diligence, it is in line with it as it implicitly but clearly acknowledges the importance of due diligence as an indicator for the establishment of legal import and fair trade in the EU by requiring the holder to be diligent in providing the necessary export and import documentation so as to ensure that the cultural goods in question were authorized to leave their country of origin. In the case of archaeological objects and parts of monuments, due diligence can be verified by indicating the appropriate support-

36 See also Articles 8 and 9 of Commission Implementing Regulation (EU) 2021/1079 of 24 June 2021 laying down detailed rules for implementing certain provisions of Regulation (EU) 2019/880 of the European Parliament and of the Council on the introduction and the import of cultural goods C/2021/4473, OJ L 234, 02.07.2021.

37 Regulation (EU) 2019/880, Article 5(2); see also Commission Implementing Regulation (EU) 2021/1079, Article 12 on the list of supporting documents to prove licit provenance that should be in the possession of the declarant.

38 European Commission, Proposal..., p. 3.

3924 June 1995, 34 ILM 1322. 


\section{DEBUTS}

Stella Sarapani

ing documents and evidence, such as export certificates, ownership titles, invoices, sales contracts, insurance documents, transport documents, and experts' appraisals. For cultural goods, the import of which does not require an import licence, the holders of such goods can be deemed diligent when they are able to certify and assume responsibility for lawful export from the third country by means of a declaration (Article 5(2)(a)), and provide every possible detail about the goods in their possession with the use of the Object ID standard, as recommended by UNESCO (Article 5(2)(b)). ${ }^{40}$ Article 8(1)(a) and Article 12(1) of the Implementing Regulation 2021/1079 also indicate the use of supporting documents as evidence of due diligence. ${ }^{41}$ The new Regulation relies on an electronic system (Article 8) for the control by customs authorities of the information provided. ${ }^{42}$ The absence or inability to provide satisfactory information, not to mention the existence of forged documents would, of course, imply a failure of due diligence. Yet the new Regulation is silent on the consequences that a failure of due diligence would imply. Considering Article 11 of this Regulation, the failure of due diligence will probably be a matter of national law and may be treated differently from one jurisdiction to another.

Evidence that a cultural good has been exported in accordance with the national laws and regulations of its country of origin "shall be provided in the form of export certificates or export licenses where the country in question has established such documents for the export of cultural goods at the time of the export". ${ }^{43}$ Yet if the country where the item was created or discovered cannot be reliably determined, or the export, creation, or discovery of this item took place before the 1970 UNESCO Convention on the Means of Prohibiting and Preventing the Illicit Import, Export and Transfer of Ownership of Cultural Property ${ }^{44}$ ("1970 UNESCO Convention"; entered into force 24 April 1972), it is then sufficient for the importer to provide evidence (in case of an import licence), or to declare (in case of an importer statement) that the cultural good in question has been exported in accordance with the laws and regulations of the "last country" where it was located for a period of more than 5 years and for purposes other than temporary use, transit, re-export, or transshipment (Article 4(4)(a) and (b), Article 5(2)(a) and (b)). This measure applies to both high-risk goods (part $B$ of the Annex) for which an import licence is required, and to low-risk goods (part $C$ of the Annex) for which only an importer statement is required according to Article 4(4) and Article 5(2) respectively. Articles 4 and 5 set

\footnotetext{
40 One can consult the ICOM Code of Ethics for Museums (1986) and the UNESCO International Code of Ethics for Dealers in Cultural Property (1999), which also provide detailed provisions on due diligence. See, respectively, https://icom.museum/wp-content/uploads/2018/07/ICOM-code-En-web.pdf and https://unesdoc.unesco.org/ark:/48223/pf0000121320 [both accessed: 11.10.2021].

41 See Article 8(1)(a) of Commission Implementing Regulation (EU) 2021/1079.

42 Arrangements and detailed rules regarding the use of the electronic system are provided in Chapter V of the Implementing Regulation 2021/1079.

43 Regulation (EU) 2019/880, Article 4(5).

4414 November 1970, 823 UNTS 231.
} 
a new due date, based this time on the entry into force of the 1970 UNESCO Convention and not on the date of establishment of the SEM (1 January 1993), as used by Regulation No. 116/2009 on the export of cultural goods. Apart from that, however, Articles 4 and 5 seem to contain a worrying concession that raises questions on the effectiveness of this Regulation. Specifically, they create a loophole for exploitation. If the holder of the cultural good does not have evidence of legal export from the country of origin but does have evidence of legal export from the country where the item has been for 5 years, then what is to stop the holder of a looted good from claiming that they cannot reliably determine the country of origin or that export took place "before 1972", and thus "park" it in another third country for 5 years, and then export the good legitimately from the "parking" country and import it into the EU by relying on the concession of Articles 4 and 5 ?

The new Regulation extends the application of its measures and establishes controls to free zones in an effort, one might say, to reduce the chances of illegal cultural goods leaking from repositories. Those controls not only concern the cultural goods released for free circulation, but also cultural goods placed under special customs procedures like storage, specific-use, and processing, which involve customs warehousing and free zones, temporary admission and end-use, as well as inward processing. This is a very important measure given the role that free ports (i.e. warehouses in free zones) can serve in the illicit trafficking of cultural goods. As stated in the Preamble of the new Regulation, free zones "have the potential to be used for the continued proliferation of illicit trade". ${ }^{45}$ Apart from being repositories for illicit cultural goods, free ports are also ideal places for money laundering activities due to the lack of controls and enforcement of regulations within these zones. In most free ports, almost anyone can bring in goods on behalf of someone else without disclosing the ultimate beneficiary, while tax evasion is possible as well, as in most cases the registered value of the goods depends exclusively on a self-declaration. ${ }^{46}$ Thus, this measure could prove effective in closing avenues for trade in illicit cultural property from third countries, especially when seen in combination with other relative initiatives. Specifically, the controls imposed by the new Regulation on free zones fit in with the 2016 and 2005 Swiss regulations (the Anti-Money Laundering Act and the Swiss Customs Act) ${ }^{47}$ for free ports and

\footnotetext{
45 Regulation (EU) 2019/880, Preamble (6).

46 R. Korver, Money Laundering and Tax Evasion Risks in Free Ports, European Parliamentary Research Service Study, October 2018, pp. 12-15; J. Zarobell, The Role of Freeports in the Global Art Market, "Artsy", 14 July 2017, https://www.artsy.net/article/artsy-editorial-freeports-operate-margins-global-art-market [accessed: 30.08 .2021 ].

47 The Swiss Anti-Money Laundering Act aims to introduce greater transparency into transactions by requiring the involvement of a financial intermediary (e.g. a bank) and from the seller to take steps to ensure the legality of the buyer's funds. See Legge Federale relativa alla lotta contro il riciclaggio di denaro e il finanziamento del terrorismo [Federal Act on Combating Money Laundering and Terrorist Financing], 10 October 1997, Raccolta Ufficiale 1998892 as amended, in force since 1 January 2016.
} 


\section{DEBUTS}

Stella Sarapani

warehouses. While this measure could work effectively in the case of cultural goods coming from repositories in Switzerland, its interaction with other cases such as that of free zones located outside the customs territory of the Union or the Schengen Area is rather questionable for the time being. In Switzerland all imported cultural goods must bear a declaration stating their origin, value, and ownership, as well as an export permit from a contracting party to the 1970 UNESCO Convention (storing cultural objects in free ports is considered an import into Switzerland and so the same declaratory requirements apply). ${ }^{48}$ If no export permit is presented, the planned import is illegal. ${ }^{49}$ In addition, an official audit for every archaeological object bound for importation in the free port is imposed..$^{50}$ In cases of goods of a dubious origin or the absence of an internationally recognized paper trail, the item is banned from entering the free zone, while customs are authorized to withhold it. ${ }^{51}$ Moreover, Switzerland bans the import and trade of cultural goods coming from Syria and Iraq via specific legal measures. ${ }^{52}$

\section{The two EU legal approaches}

Compared to the first EU legal approach on the protection of non-EU cultural goods, that is the ad hoc measures for Syria and Iraq, the new Regulation is more comprehensive and specific, focusing exclusively on the protection of all non-EU cultural property. It also provides a wider range of protection, covering all third countries that are a source for the illicit trade in cultural goods. This new element is more than important, and in view of the current political as well as humanitarian crisis in Afghanistan, one would agree that this new element is timely and permits the EU to be one step ahead in protecting, when necessary, Afghanistan's cultural heritage. ${ }^{53}$ Moreover, the new Regulation complements the existing EU laws

The Swiss Customs Act imposes a six-month time limit on goods stored in the free port and obliges free port managers to identify owners in the warehouse inventory records. See Legge sulle dogane [Customs Act], 18 March 2005, Raccolta Ufficiale 2007 1411; Ordinanza sulle dogane [Ordinance of the Customs], 1 November 2006, Raccolta Ufficiale 20071469.

48 Articles $4 a$ and 19 of Legge Federale sul trasferimento internazionale dei beni culturali [Federal Act on the International Transfer of Cultural Property], 20 June 2003, Raccolta Ufficiale 20051869 as amended (CPTA); Article 25 of Ordinanza sul trasferimento internazionale dei beni culturali [Cultural Property Transfer Ordinance], 13 April 2005, Raccolta Ufficiale 20051883 (CPTO).

49 Article 24(1)(c) CPTA.

50 Article 19 CPTA and Article 23 CPTO.

51 Article 19 CPTA and Article 104 of the Customs Act of 2005.

52 Ordinanza che istituisce misure economiche nei confronti della Repubblica dell'Iraq [Ordinance on Economic Measures against the Republic of Iraq], 7 August 1990, Raccolta Ufficiale 1990 1316; Ordinanza che istituisce provvedimenti nei confronti della Siria [Ordinance on Measures against Syria], 8 June 2012, Raccolta Ufficiale 20123489.

53 ICOM, Statement Concerning the Situation Facing Cultural Heritage in Afghanistan, 17 August 2021, https://icom.museum/en/news/statement-concerning-the-situation-facing-cultural-heritage-in-afghanistan/ [accessed: 11.10.2021]; UNESCO, Afghanistan - UNESCO Calls for the Protection of Cultural Heritage 
on trade in cultural goods and imposes common import rules across the Member States. The Member States now have at their disposal a comprehensive set of legal measures to combat illicit trade, which creates uniformity at the EU level and also is in line with the existing international rules in the area. At the same time however, the provisions of Articles 4 and 5 of the new Regulation and the loophole it creates are quite concerning, as it seems that under the new Regulation it does not ultimately matter whether the imported object has no provenance or whether its provenance is in between Syria, Iraq, or any other third country, as long as it can be proven by documents that it was exported in accordance with the laws and regulations of the "last country" in which it has been for more than 5 years. This applies also in the situation where the country of origin is known and export was before 1972. To put it simply, the new Regulation does not insist on proving the provenance of cultural goods when those come from the "last country". In this way, it opens the back door to those who traffic cultural goods from Iraq and Syria as well as other third countries. It allows them to use intermediary countries until they can legally import looted cultural goods into the EU. Of course, not all third countries can be an easy channel. Countries like Switzerland, where a comprehensive legal framework is in place to prevent the illegal importation of cultural goods, could close the avenue to illicit cultural goods more effectively than other third countries, where the lack of a corresponding legal framework could favour the import and eventually the channelling of illicit cultural goods into the EU through the loophole of the new Regulation. For the Member States, in turn, and especially those on the front line of the EU's North-Eastern Mediterranean boundaries, such as Greece, Cyprus, and Bulgaria, which are in geographical proximity to third countries like Turkey, Lebanon, and Syria, this loophole constitutes a challenge, which may affect the adequacy of the new Regulation. It should be noted here for the sake of clarity that reference is made to Turkey and Lebanon because both have been identified as primary destinations for looted cultural goods derived from the war zones of Syria and Iraq, with which these countries border. ${ }^{54}$

In order to be fully understood, the argument stated above must be seen from the perspective of one of these Member States in the North-Eastern Mediterranean. In this sense the choice of Greece is ideal because of its geographical location at the crossroads between Europe, Asia, and Africa, and because it is a country rich in archaeological material itself, a fact that implies the imposition of strict national legislation for the protection of cultural heritage. It is, therefore, interesting to see the interaction between the EU and national import rules, and exactly what Articles 4(4) and 5(2) of the new Regulation could mean for Greece.

and Its Diversity, 19 August 2021, https://en.unesco.org/news/afghanistan-unesco-calls-protection-cultural-heritage-its-diversity [accessed: 11.10.2021].

54 C.A. Weirich, op. cit., pp. 6-7. 


\section{DEBUTS}

Stella Sarapani

As explained above, Articles 4(4) and 5(2) create a loophole for exploitation because of the "last country" provision. It seems that an illicit cultural good has the potential to pass into the Greek territory through any "last country" in its proximity, because in the "last country" this item can actually become legal. Falsified documents obtained in transit locations can be used before customs authorities as evidence of provenance..$^{55}$ This transformation of the legal status (i.e. from illicit to licit), which is very common in this type of illegal trade, ${ }^{56}$ can allow an illicit cultural good from the war zones of the Middle East or from any other third country to enter Greece, especially when this item is a product of clandestine excavation. Looted cultural goods have no provenance due to their illegal nature; they are goods that are not reported to the authorities or registered in national catalogues so as to be easily traceable in the event of unlawful removal and identifiable as being of fraudulent legitimacy. In Syria, for instance, there is also an acknowledged problem of inadequate documentation of antiquities in the State. ${ }^{57}$ Looted cultural goods are, therefore, very vulnerable to the aforementioned practices. This seems not to be fully perceived by the new Regulation, whereby Articles 4(4) and 5(2) in practice allow the holder to use the "last country" as the place of legitimate export for goods that in fact are illicit but have become licit during their stay in this "last country". While the new Regulation seems at first glance to provide an alternative under Articles 4(4) and 5(2), in essence it allows this transformation in the legal status of third-country cultural goods. Thus instead of blocking their passage to the EU, it allows their entrance through the back door. Under the cloak of legitima$c y$, these items can then continue their route within the SEM to market countries. Also, the two prerequisites set out in those Articles for the use of the "last country" provision, i.e. indeterminate origin and export before 1972, seem to be more of an opportunity for those trafficking in cultural goods from third countries to create a fake provenance and can be used as an excuse before customs authorities for the importation of illicit third-country cultural goods into the EU. Therefore instead of rectifying the weakness observed in the restrictive measures for Syria and Iraq, it rather maintains it. ${ }^{58}$ Who would identify a looted Syrian antiquity that carries a foreign "passport" upon its import into Greece? The holder, who does not have evidence of legal export from Syria, does have evidence of legal export from the "last country".

55 S. Calvani, Frequency and Figures of Organized Crime in Art and Antiquities, in: S. Manacorda (ed.), Organised Crime in Art and Antiquities, ISPAC International Scientific and Professional Advisory Council of the United Nations Crime Prevention and Criminal Justice Programme, Milano 2009, p. 34.

56 S. Mackenzie, D. Yates, What is Grey About the "Grey Market" in Antiquities?, in: J. Beckert, M. Dewey (eds.), The Architecture of Illegal Markets: Towards an Economic Sociology of Illegality in the Economy, Oxford University Press, Oxford 2016, pp. 75-76.

57 R. Mackenzie-Gray Scott, op. cit., p. 218.

58 A.-M. Carstens, E. Varner, op. cit., p. 382; N. Brodie, Syria..., p. 323. 
This example displays not only the way in which the traffickers of cultural goods could take advantage of the loophole created by the new Regulation, but also the role of other key third countries in this type of trade. During the civil unrest in Syria, looted material was reported passing out of Syria into Lebanon, Jordan, and Turkey ${ }^{59}$ While there are generally little data in this regard, it is estimated that almost 16,000 cultural goods from Syria alone have been seized in Europe since 2017 and the adoption of UNSC Resolution 2347. Worldwide, since 2014 there have been 231 seizures, corresponding to 166,246 objects from the Middle East and North Africa (MENA) region, mainly in source or intermediary countries such as Turkey (87), Egypt (59), and Syria (16), while few have been detected in destination countries such as the United States (US) (13) and France (5)..$^{60}$ The case of California dealer Mohamad Yassin Alcharihi is indicative as regards the latter. In 2015, Alcharihi imported into the US a Byzantine mosaic shipped by sea from Iskenderun in Turkey, which according to the FBI had probably been exported illegally from Syria. ${ }^{61}$ As one understands the current status of the legal protections, third countries used as an intermediary station in this type of illicit trade are in a position to challenge the effectiveness of the new Regulation in terms of its aim of limiting the import of non-EU cultural goods into the Union's territory due to their potential to be used as storage for illicit cultural goods. Indicatively, since 2013 Turkish law enforcement agencies recorded 1,366 cases of attempted illegal export of cultural goods from Turkey to the EU, thus demonstrating the extent of the problem. ${ }^{62}$ Greece, which shares a land and maritime border with Turkey, has concluded a bilateral agreement ${ }^{63}$ with its neighbouring State for the prevention of illicit trafficking in cultural goods that includes, inter alia, mutual cooperation in preventing the illegal import of cultural goods removed unlawfully from the Parties' territories. The agreement thus focuses on Greek and Turkish cultural property. It does not refer to other States' cultural goods moving to/from the Parties' territories.

\footnotetext{
59 N. Brodie, Syria..., p. 318.

60 V. Michel, Illegal Trafficking of Cultural Goods in Countries in Conflict, 7 October 2020, https://netcher.eu/ project-news/illegal-trafficking-of-cultural-goods-in-countries-in-conflict/ [accessed: 11.10.2021].

61 N. Brodie, Countering Looting of Antiquities in Syria and Iraq. Final Report, Terrorism, Transnational Crime and Corruption Center (TraCCC) of George Mason University, Arlington/Virginia (U.S.), 7 January 2019, pp. 7-10, https://traccc.gmu.edu/wp-content/uploads/2020/10/Final-TraCCC-CTP-CTAQM-17-006-Report-Jan-7-2019.pdf [accessed: 11.10.2021]; United States of America v One Ancient Mosaic, United States District Court, Central District of California, Western Division, Judgment of 23 March 2018 (18-CV-04420).

62 European Commission, Fighting Illicit Trafficking..., p. 108.

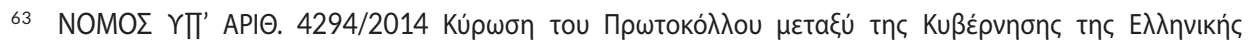

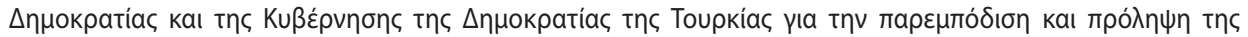

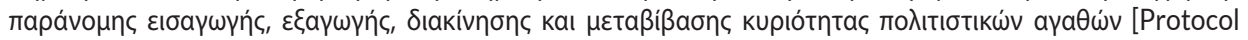
between the Government of the Hellenic Republic and the Government of the Republic of Turkey on the Prohibition and Prevention of the Illicit Import, Export, Transit, and Transfer of Ownership of Cultural Property], Government Gazette A 211/30.09.2014.
} 


\section{DEBUTS}

Stella Sarapani

The EU, in turn, concluded on March 2016 an agreement ${ }^{64}$ with Turkey for the refugees and migrants from third countries arriving through Turkey into the EU, and in particular into the Greek islands and the Balkans, but no agreement has been concluded between the EU and Turkey on the movement of third-country cultural goods through the Turkish territory into the EU territory.

\section{Import Rules in Greece}

\section{National Law No. 3028/2002 and rules of international law}

In terms of national law, Greece is a country with strict legislation when it comes to cultural heritage,,$^{65}$ the protection of which is an obligation that stems from the Constitution and is enshrined in its Article 24. ${ }^{66}$ The main legal instrument in this area is Law No. 3028/2002 on the protection of antiquities and cultural heritage in general. ${ }^{67}$ As a legislative text, Law 3028/2002 includes criminal and administrative provisions, and provisions of civil law regarding the ownership of cultural heritage, thus providing an enhanced protection regime. ${ }^{68}$

64 Council of the EU, EU-Turkey Statement, 18 March 2016, Press release 114/16, https://www.consilium. europa.eu/en/press/press-releases/2016/03/18/eu-turkey-statement/pdf [accessed: 24.10.2021].

65 Law 3028/2002 uses the term "cultural heritage" instead of "cultural property". Therefore, this part of the article follows the national law in terms of terminology. It should be noted, however, that these two terms are not identical. While they are sometimes used interchangeably, there is a difference between them. The term "cultural property" is closer to property law and ownership rights, while the term "cultural heritage" is a broader term that encompasses duties such as the duty of protecting this heritage for future generations. I. Stamatoudi, Cultural Property Law and Restitution, Edward Elgar Publishing, Cheltenham 2011, pp. 6-8; M. Frigo, Cultural Property v. Cultural Heritage: A "Battle of Concepts" in International Law?, "International Review of the Red Cross" 2004, Vol. 86(854), p. 367; L.V. Prott, P.J. O'Keefe, 'Cultural Heritage' or 'Cultural Property'?, "International Journal of Cultural Property" 1992, Vol. 1, p. 307.

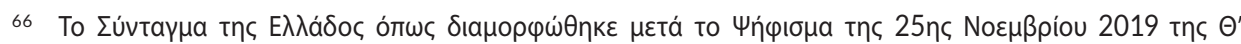

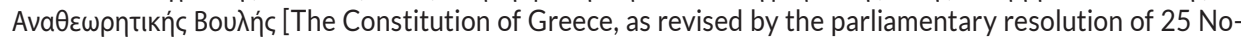
vember 2019 of the IX Revisionary Parliament], Government Gazette A 187/28.11.2019; I. Stamatoudi, Greek Law 4355/2015 Implementing Directive 2014/60/EU on the Return of Cultural Objects Unlawfully Removed from the Territory of a Member State, "Santander Art and Culture Law Review" 2016, Vol. 2, pp. 57-59.

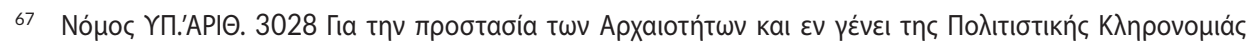
[Law No. 3028/2002 on the Protection of Antiquities and Cultural Heritage in General], Government Gazette A 153/28.06.2002; for the commentary on this piece of legislation see: E.N. Moustaira, Greece, in: J.A.R. Nafziger, R.K. Paterson, Handbook on the Law of Cultural Heritage and International Trade, Edward Elgar Publishing, Cheltenham 2014, pp. 177-187.

68 Law 3028/2002 is the first systematic and complete legislation after 1932 for the protection of antiquities and cultural heritage in general. As stated in the Explanatory Report, the concept of cultural heritage is expanded, the cultural heritage is organized and systematized on the basis of a chronological system, the property rights over cultural heritage are redefined, and the criminal measures are enriched, while the protection of cultural heritage takes on a social dimension as co-operation is established with the citizen, with

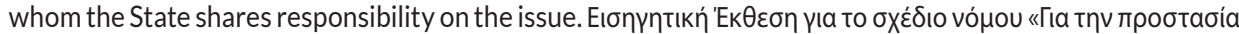

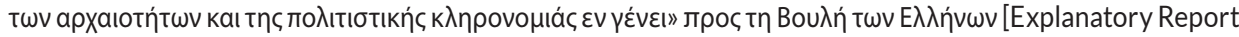
on the Draft Law "On the Protection of Antiquities and Cultural Heritage in General" to the Greek Parliament], 21 May 2002. 
The object of protection of Law 3028/2002 is primarily "the cultural heritage of the country from the most ancient times until today" (Article 1(1)(a)) and by this it means all the cultural goods that are within the borders of the Greek State, including its territorial waters as well as within the sea zones in which Greece exercises relevant jurisdiction in accordance with international law. The cultural heritage of the country includes all the cultural goods which are in the Greek territory, including, in terms of protection, all cultural goods of foreign origin located or legally imported into Greece. ${ }^{69}$ Based on this latter provision, Article 33 of Law 3028/2002, which regulates the import of cultural goods into the Greek territory, should be taken into account.

Under the said Article, cultural goods can be imported freely into Greece, provided that the provisions of the 1970 UNESCO Convention and other rules of international law are not violated. The holder of imported goods must, without undue delay, declare their import to the Archaeological Service as well as the manner in which they came to his/her possession. ${ }^{70}$ This measure makes Greece the only country in the EU requiring a declaration upon import. ${ }^{71}$ The right of ownership of legally imported antiquities ${ }^{72}$ dated up to 1453 is maintained unless a) they had been exported from Greece during the last 50 years before the importation; and b) they have not been illegally removed from a monument, an archaeological site, church, public collection, collection of religious monuments, storage places of archaeological finds from excavations or other similar places, and they are not product of illegal excavations within Greek territory. If the Archaeological Service considers that they had been exported from Greece during the previous 50 years or that they are products of illegal activities, the holder has to provide evidence of the antiquity's acquisition or import and has to prove its origin. If it is not possible to prove origin, a permit of possession (but not a right of ownership ${ }^{73}$ ) will be granted unless the applicant does not provide the necessary safeguards of compliance;

69 D. Papapetropoulos, Protection of the Archaeological and Modern Cultural Heritage: By Article Interpretation of Law No. 3028/2002, Sakkoulas Publications, Athens 2017, p. 2 (in Greek).

70 Law 3028/2002, Article 33(2).

71 European Commission, Fighting Illicit Trafficking..., pp. 88-89.

72 Law 3028/2002 distinguishes cultural goods by classifying them as antiquities or ancient monuments, recent monuments, movables, and immovables. Under Article 2(b)(i) of Law 3028/2002, "ancient monuments or antiquities mean all cultural objects dating back to prehistoric, ancient, Byzantine and post-Byzantine times up to $1830 "$.

73 The Greek legal system divides the natural power over an object into two different rights: [katoxń] and [vouń] (Articles 973-974 of the Civil Code [CC]). Given that neither English nor U.S. law recognize a corresponding distinction, the English translation of these two different property rights cannot be interpreted otherwise than "possession". Among the rights in rem, according to Article 973 CC, is [kupıótnta] (literally: ownership). Ownership as opposed to the (second) term [vouń], which is a real situation and a creation of the legal system and is understood only within the framework of the legal system. I. Karakostas, Civil Code, Law Library Publications, Athens 2021 (in Greek); G. Bali, Property Law, Pyrsos Publications, Athens 1951, p. 86 (in Greek). 


\section{DEBUTS}

Stella Sarapani

in particular if he/she has been sentenced irrevocably for a felony, violation of the legislation for the protection of cultural heritage, forgery, bribery, theft, embezzlement, or receiving the proceeds of crime. These impediments exist for as long as criminal proceedings are pending. ${ }^{74}$

Therefore, the import of cultural goods in Greece is basically free so long as it does not violate the rules of international laws on the export of cultural goods. According to Article 6 of the 1970 UNESCO Convention, State Parties should "introduce an appropriate certificate in which the exporting State would specify that the export of the cultural property in question is authorized. The certificate should accompany all items of cultural property exported in accordance with the regulations". Greek law ${ }^{75}$ adopts this rule of international law, which was also included in Law 3028/2002, and therefore a certificate of legal export from the exporting State is required at the national level upon import. When this rule is violated and consequently the import into Greece is illegal, then Article 6476 of Law 3028/2002 applies, which provides for penalties, and specifically for imprisonment for not less than 1 year. It follows from this provision that the legislator is less strict with regard to the import of cultural goods than to their export, which is actually punished under this Law with a temporary term not exceeding 10 years (Article 63). Nevertheless, there is no freedom of import with regard to cultural goods illegally exported from another State. Their entry into Greece is prevented and such an act is punishable criminally in accordance with Article 64 of this Law.

At this point a question inevitably arises: Is the "last country" considered the exporting State within the meaning of Article 6 of the 1970 UNESCO Convention, even if the country of creation or discovery is different? If so, then very simply there is no violation of international law and import into Greece is legal.

When the cultural goods meet the import requirements to enter Greece legally, then the next step is a declaration to the national authorities. Some categories of cultural goods require a special declaration to the authorities (Article 33(2)), oth-

\footnotetext{
74 Law 3028/2002, Article 33(3).

75 The 1970 UNESCO Convention was transposed into the Greek legal order by Nópoc 1103/1980 Пعрí

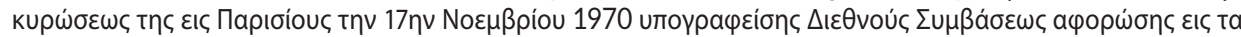

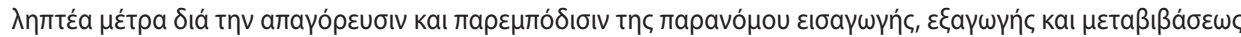

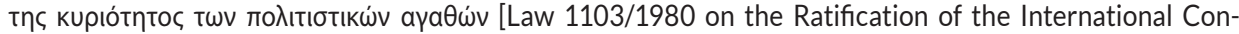
vention, Signed in Paris on 17 November 1970, Concerning Measures to be Taken to Prohibit and Prevent the Illegal Import, Export, and Transfer of Ownership of Cultural Property], Government Gazette A 297/29.12.1980.

76 Law 3028/2002, Article 64: "Any person who imports into Greek territory cultural goods under the terms of the 1970 UNESCO Convention, which have been illegally removed from museums or other similar institutions or religious or public monuments situated within the territory of other States Parties to the said Convention and which are documented as appertaining to the inventory of those institutions shall be punished by imprisonment for not less than one (1) year, if the act is not punishable more severely by another provision".
} 
erwise imprisonment may be imposed in accordance with Article 58 of this Law. ${ }^{77}$ Certain cultural goods (those dating before 1453$)^{78}$ require their declaration to the authorities (Article 33(2)), and failure to do so is punishable by a temporary term ${ }^{79}$ not exceeding 2 years. ${ }^{80}$

As mentioned, the right of ownership in antiquities dating before 1453 is maintained under certain conditions (Article 33(3)). This is actually the only exception under Law 3028/2002, which recognizes private property rights to ancient cultural goods. However, the holder must be able to provide evidence of acquisition or import, as well as prove the provenance of the items in question if the responsible authority considers that they have been exported from Greece during the last 50 years before import or that they are the products of the aforementioned illegal acts. ${ }^{81}$ The proof of provenance of the imported item plays a significant role in providing ownership title. In other words, Law 3028/2002 treats the importer as the holder at the time of import and not as the owner, because the issue of ownership is not decided at that time but later, after the provenance of the items is definitive. If it turns out that the cultural goods have in fact been illegally obtained, they are then imprescriptible and res extra commercium within the meaning of Article 966 of the Civil Code (Articles 33(3) and 21(1) ${ }^{82}$.

Law 3028/2002 uses the statuses of imprescriptibility and res extra commercium to place limitations on property rights for certain categories of cultural goods. Referring to a cultural good as inalienable or imprescriptible indicates that the item is of such great importance that it cannot be transferred. The State has the imprescriptible or inalienable right over such a cultural good, and it cannot be alienated from the State's rights - no third party, regardless of whether or not they are good faith purchasers or otherwise obtained the good in good faith, can achieve ownership in any way, including short- or long-term possession. ${ }^{83}$ Thus, if it turns out that cultural goods have been obtained illegally, their legal status changes, and as such they cannot be transferred and they pass onto the State in terms of ownership. The holder may maintain his/her right to possession in the event the provenance of

\footnotetext{
77 Law 3028/2002, Article 58: "Any person who fails to make a declaration pursuant to the provisions of article 33, paragraph 2, shall be punished by a term of imprisonment not exceeding two (2) years".

78 Law 3028/2002, Article 20(1)(a), (b), and (6).

79 It should be noted that in Greek law a sentence of temporary term is different from imprisonment. The former lasts from 5 years to 20 years, while the latter lasts from 10 days to 5 years.

80 Law 3028/2002, Article 58.

81 See E.N. Moustaira, op. cit., pp. 181-183.

82 Law 3028/2002, Article 21: "1. Movable ancient monuments dating up to 1453 belong to the State in terms of ownership and possession, are imprescriptible and res extra commercium within the meaning of article 966 of the Civil Code. 3. Ancient movable monuments which are finds from excavations or other archaeological research, regardless of their dating, belong to the State in terms of ownership and possession, are res extra commercium and imprescriptible".

83 I. Stamatoudi, Cultural Property Law..., p. 40.
} 


\section{DEBUTS}

Stella Sarapani

the items cannot be determined, provided that there are no impediments against him/her such as those mentioned above.

\section{Final Remarks}

Greek Law 3028/2002 is not adequate with regard to the importation of cultural goods originating from other countries in general. This law alone could not restrict the flow of illicit cultural goods into Greece, regardless of whether such items originate from a third country or even a Member State, a fact that reflects at the same time a major weakness of the 1970 UNESCO Convention, which provides in Article 7(b)(i) that: "State Parties should prohibit the import of cultural property stolen from a museum or another similar institution within the territory of a State Party to this Convention, provided that such property is documented as appearing in the inventory of that institution". There is, obviously, an unfortunate requirement within Article 7(b)(i) that seems to indicate that anything else non-registered, such as products of clandestine excavations, can be legally imported. Could that be possible?

Greece is arguably better equipped to control the import of non-EU cultural goods after the imposition of the new Regulation. However, the "last country" provision, in conjunction with the limited character of Article 33 of Law 3028/2002, very likely will not stop the import of certain cultural goods from third countries into the Greek territory and, consequently, into the EU, for all reasons mentioned. As such, illicit cultural goods from third countries could enter Greece because of these legal loopholes and a "cocktail" of other weaknesses: a) they may not be listed in national catalogues; and b) therefore their provenance could not be reliably determined; c) they can obtain export documents from the "last country", and d) on top of this, remain in the possession of the importer in accordance with Law 3028/2002.

On 2 March 2021, Greece ratified the Council of Europe Convention on Offences relating to Cultural Property ("Nicosia Convention"), ${ }^{84}$ specifically dealing with the criminalization of the illicit trafficking of cultural property. Although this treaty has not yet entered in force, it has the potential to strengthen the domestic criminal laws of the State Parties to this Convention. In this regard, the provisions of the Nicosia Convention could supplement the penal sanctions imposed by the Greek legal order for offences against cultural heritage, such as the previously-mentioned Article 64 of Law 3028/2002. As neither the 1970 UNESCO Convention nor the 1995 UNIDROIT Convention deal with criminal law issues, the Nicosia Convention thereby enhances law enforcement capacity by requiring States Parties to implement several important provisions concerning 
cultural property into their criminal law, further ensuring the ability to investigate, prosecute, sentence, and/or extradite persons suspected or convicted of offences falling under the ambit of this treaty. ${ }^{85}$

The Nicosia Convention criminalizes the import of cultural goods that constitute products of clandestine excavations, both in land or underwater; the import of cultural goods which have been stolen in another State; and the import of cultural goods which have been unlawfully removed in violation of the law of the State that considers the imported property as part of its own cultural heritage. ${ }^{86}$ The penal sanctions to these offences should be proportionate and dissuasive, taking into account the seriousness of the offence, and may include penalties involving primarily deprivation of liberty and/or administrative sanctions (Article 14). Except in the case of an offence in accordance with Article 4(1)(a) and Article 5(1)(b and c), States Parties must provide for prison sanctions that can give rise to extradition, which under Article 2 of the European Convention on Extradition ${ }^{87}$ is to be granted in respect of offences punishable under the laws of the requesting State by deprivation of liberty or under a detention order for a maximum period of at least 1 year, or by a more severe penalty. Last but not least, the commission of a criminal offence in the framework of a criminal organization is considered as an aggravating circumstance under the Nicosia Convention (Article 15(c)), a provision that reflects the commonly-accepted link between cultural heritage and terrorism financing. The Convention, however, does not define the term "criminal organization". States Parties need to refer to other international instruments which define this concept (as suggested by the Explanatory Repor $\mathrm{t}^{88}$ ), such as the 2000 United Nations Convention against Transnational Organized Crime..$^{89}$ The Greek Penal Code also recognizes the possibility of a link between cultural heritage and organized criminal groups in its Article 187(1), whereby it brings the offences against cultural heritage into the sphere of organized crime and imposes a temporary term of 10 years maximum to organized criminal groups committing the offences laid down in Law 3028/2002. ${ }^{90}$ Unless and until the Nicosia Convention will enter into force, it remains to be seen precisely what its effects would be.

85 Council of Europe, Explanatory Report to the Council of Europe Convention on Offences relating to Cultural Property, 19 May 2017, CETS 221, p. 3.

86 Ibidem, p. 8.

87 Council of Europe Convention on Extradition, 12 December 1957, ETS 24.

88 Council of Europe, Explanatory Report..., p. 15.

89 The UN Convention against Transnational Organized Crime (2000) has, under Article 3(2), defined transnational crime as an offence whose actualization, preparation, prevention, and effect involve more than one State. Greece ratified the Convention on 11 January 2011. United Nations Convention against Transnational Organized Crime and the Protocols Thereto, 15 November 2000, 2225 UNTS 209.

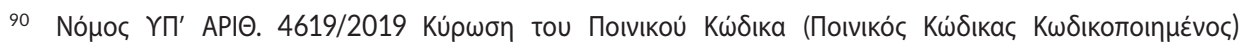
[Ratification of the Penal Code (Codified Penal Code)], Government Gazette A 95/11.06.2019. 


\section{References}

Bali G., Property Law, Pyrsos Publications, Athens 1951 (in Greek).

Brodie N., Countering Looting of Antiquities in Syria and Iraq. Final Report, Terrorism, Transnational Crime and Corruption Center (TraCCC) of George Mason University, Arlington/ Virginia (U.S.), 7 January 2019, https://traccc.gmu.edu/wp-content/uploads/2020/10/ Final-TraCCC-CTP-CTAQM-17-006-Report-Jan-7-2019.pdf [accessed: 11.10.2021].

Brodie N., Syria and its Regional Neighbors: A Case of Cultural Property Protection Policy Failure?, "International Journal of Cultural Property" 2015, Vol. 22(2-3).

Calvani S., Frequency and Figures of Organized Crime in Art and Antiquities, in: S. Manacorda (ed.), Organised Crime in Art and Antiquities, ISPAC International Scientific and Professional Advisory Council of the United Nations Crime Prevention and Criminal Justice Programme, Milano 2009.

Carstens A.-M., Varner E., Intersections in International Cultural Heritage Law, Oxford University Press, Oxford-New York 2020.

Commission Implementing Regulation (EU) 2021/1079 of 24 June 2021 laying down detailed rules for implementing certain provisions of Regulation (EU) 2019/880 of the European Parliament and of the Council on the introduction and the import of cultural goods C/2021/4473, OJ L 234, 02.07.2021.

Council of Europe Convention on Extradition, 12 December 1957, ETS 24.

Council of Europe Convention on Offences relating to Cultural Property, 19 March 2017, CETS 221.

Council of Europe, Explanatory Report to the Council of Europe Convention on Offences relating to Cultural Property, 19 May 2017, CETS 221.

Council of the EU, EU-Turkey Statement, 18 March 2016, Press release 114/16, https://www. consilium.europa.eu/en/press/press-releases/2016/03/18/eu-turkey-statement/pdf [accessed: 24.10.2021].

Council Regulation (EC) No. 116/2009 of 18 December 2008 on the export of cultural goods (Codified version), OJ L 39, 10.02.2009, p. 1.

Council Regulation (EC) No. 1210/2003 of 7 July 2003 concerning certain specific restrictions on economic and financial relations with Iraq and repealing Regulation (EC) No. 2465/96, OJ L 169, 8.07.2003, p. 6.

Council Regulation (EU) No. 1332/2013 of 13 December 2013 amending Regulation (EU) No. 36/2012 concerning restrictive measures in view of the situation in Syria, OJ L 335, 14.12.2013, p. 3.

Dempsey C., Mapping the Destruction of UNESCO World Heritage Sites, "Geography Realm", 25 January 2016, https://www.geographyrealm.com/mapping-the-destruction-of-unesco-world-heritage-sites/ [accessed: 24.09.2021].

Directive 2014/60/EU of the European Parliament and of the Council of 15 May 2014 on the return of cultural objects unlawfully removed from the territory of a Member State and amending Regulation (EU) No. 1024/2012 (Recast), OJ L 159, 28.05.2014, p. 1.

Directorate for Strategic Planning, Report of the General Secretariat of Public Revenue (GSPR) for the Year 2016 and Planning of Activities of the Independent Authority for Public Revenue (IAPR), March 2017, https://www.aade.gr/sites/default/files/2017-06/apologistiki_ekthesi_2016.pdf [accessed: 11.10.2021] (in Greek). 
European Commission, Communication from the Commission to the European Parliament and the Council on an Action Plan for Strengthening the Fight Against Terrorist Financing, 2 February 2016, $\operatorname{COM(2016)} 50$ final.

European Commission, Communication from the Commission to the European Parliament, the Council, the European Economic and Social Committee and the Committee of the Regions: The European Agenda on Security, 28 April 2015, COM(2015) 185 final.

European Commission, Fighting Illicit Trafficking in Cultural Goods: Analysis of Customs Issues in the EU. Final Report, June 2017, https://op.europa.eu/en/publication-detail/-/publication/fadd3791-aa40-11e7-837e-01aa75ed71a1/language-en [accessed: 11.10.2021].

European Commission, G20 Leaders' Statement on Countering Terrorism, 7 July 2017, https:// ec.europa.eu/commission/presscorner/detail/en/STATEMENT_17_1955 [accessed: 11.10.2021].

European Commission, Proposal for a Regulation of the European Parliament and of the Council on the Import of Cultural Goods, 13 July 2017, COM(2017) 375 final.

European Commission, Questions and Answers on the Illegal Import of Cultural Goods Used to Finance Terrorism, 13 July 2017, https://ec.europa.eu/commission/presscorner/detail/ en/MEMO_17_1954 [accessed: 11.10.2021].

European Parliament, Briefing: Regulating Imports of Cultural Goods, EPRS, 28 June 2019.

European Parliament, Joint Motion for a Resolution on the Destruction of Cultural Sites Perpetrated by ISIS/Da'esh, 28 April 2015, 2015/2649(RSP), https://www.europarl.europa. eu/doceo/document/RC-8-2015-0375_EN.html?redirect [accessed: 11.10.2021].

Frigo M., Cultural Property v. Cultural Heritage: A "Battle of Concepts" in International Law?, "International Review of the Red Cross" 2004, Vol. 86(854).

G7 Taormina Statement on the Fight Against Terrorism and Violent Extremism, http://www. g7italy.it/sites/default/files/documents/G7\%20Taormina\%20Statement\%20on\%20 the\%20Fight\%20Against\%20Terrorism\%20and\%20Violent\%20Extremism/index. pdf [accessed: 11.10.2021].

Greece a Transit Country for Trade in Illicit Antiquities from Syria, Iraq, "Kathimerini”, 24 January 2016, https://www.ekathimerini.com/news/205358/greece-a-transit-country-fortrade-in-illicit-antiquities-from-syria-iraq/ [accessed: 02.07.2021].

ICOM, Code of Ethics for Museums, 2017, https://icom.museum/wp-content/uploads/2018/ 07/ICOM-code-En-web.pdf [accessed: 11.10.2021].

ICOM, Statement Concerning the Situation Facing Cultural Heritage in Afghanistan, 17 August 2021, https://icom.museum/en/news/statement-concerning-the-situation-facing-cultural-heritage-in-afghanistan/ [accessed: 11.10.2021].

John M., 'Blood Antiquities': A Wound the World Struggles to Staunch, "Reuters", 10 June 2015, https://www.reuters.com/article/us-mideast-crisis-antiquities-analysis-idUSKBN0OQ16320150610 [accessed: 11.10.2021].

Kami A., Sumerian Gold Jar, Other Relics Returned to Iraq, "Reuters", 30 January 2012, https:// www.reuters.com/article/us-iraq-artefacts-idUSTRE80T12J20120130 [accessed: 28.08.2021].

Karakostas I., Civil Code, Law Library Publications, Athens 2021 (in Greek).

Korver R., Money Laundering and Tax Evasion Risks in Free Ports, European Parliamentary Research Service Study, October 2018. 


\section{DEBUTS}

Stella Sarapani

Legge Federale relativa alla lotta contro il riciclaggio di denaro e il finanziamento del terrorismo [Federal Act on Combating Money Laundering and Terrorist Financing], 10 October 1997, Raccolta Ufficiale 1998892 (amended).

Legge Federale sul trasferimento internazionale dei beni culturali [Federal Act on the International Transfer of Cultural Property], 20 June 2003, Raccolta Ufficiale 20051869 (amended).

Legge sulle dogane [Customs Act], 18 March 2005, Raccolta Ufficiale 20071411.

Mackenzie S., Yates D., What is Grey About the "Grey Market" in Antiquities?, in: J. Beckert, M. Dewey (eds.), The Architecture of Illegal Markets: Towards an Economic Sociology of Illegality in the Economy, Oxford University Press, Oxford 2016.

Mackenzie-Gray Scott R., The European Union's Approach to Trade Restrictions on Cultural Property: A Trendsetter for the Protection of Cultural Property in Other Regions?, "Santander Art and Culture Law Review" 2016, Vol. 2.

McGivern H., Palmyra Antiquities Seized at Geneva Free Port, "The Art Newspaper", 5 December2016,https://www.theartnewspaper.com/news/palmyra-antiquities-seized-at-geneva-free-port [accessed: 26.09.2021].

Michel V., Illegal Trafficking of Cultural Goods in Countries in Conflict, 7 October 2020, https:// netcher.eu/project-news/illegal-trafficking-of-cultural-goods-in-countries-in-conflict/ [accessed: 11.10.2021].

Moustaira E.N., Greece, in: J.A.R. Nafziger, R.K. Paterson, Handbook on the Law of Cultural Heritage and International Trade, Edward Elgar Publishing, Cheltenham 2014.

Ordinanza che istituisce misure economiche nei confronti della Repubblica dell'Iraq [Ordinance on Economic Measures against the Republic of Iraq], 7 August 1990, Raccolta Ufficiale 19901316.

Ordinanza che istituisce provvedimenti nei confronti della Siria [Ordinance on Measures against Syria], 8 June 2012, Raccolta Ufficiale 20123489.

Ordinanza sul trasferimento internazionale dei beni culturali [Cultural Property Transfer Ordinance], 13 April 2005, Raccolta Ufficiale 20051883.

Ordinanza sulle dogane [Ordinance of the Customs], 1 November 2006, Raccolta Ufficiale 20071469.

Papapetropoulos D., Protection of the Archaeological and Modern Cultural Heritage: By Article Interpretation of Law No. 3028/2002, Sakkoulas Publications, Athens 2017 (in Greek).

Prott L.V., O'Keefe P.J., 'Cultural Heritage' or 'Cultural Property'?, “International Journal of Cultural Property" 1992, Vol. 1.

Regulation (EU) 2019/880 of the European Parliament and of the Council of 17 April 2019 on the introduction and the import of cultural goods, OJ L 151, 7.06.2019, p. 1.

Revenu N., Un Trésor Archéologique Saisi à Roissy, "Le Parisien”, 21 September 2016, https://www.leparisien.fr/faits-divers/un-tresor-archeologique-saisi-a-roissy-21-09-2016-6136959.php [accessed: 26.09.2021].

Sakellis Y., Spyropoulou N., Ziomas D., The Refugee Crisis in Greece in the Aftermath of the 20 March 2016 EU-Turkey Agreement, ESPN Flash Report 2016/64, August 2016, https://www.europeansources.info/record/the-refugee-crisis-in-greece-in-the-aftermath-of-the-20-march-2016-eu-turkey-agreement/ [accessed: 11.10.2021].

Stamatoudi I., Cultural Property Law and Restitution, Edward Elgar Publishing, Cheltenham 2011. 
Stamatoudi I., Greek Law 4355/2015 Implementing Directive 2014/60/EU on the Return of Cultural Objects Unlawfully Removed from the Territory of a Member State, "Santander Art and Culture Law Review" 2016, Vol. 2.

UNESCO, Afghanistan - UNESCO Calls for the Protection of Cultural Heritage and Its Diversity, 19 August 2021, https://en.unesco.org/news/afghanistan-unesco-calls-protection-cultural-heritage-its-diversity [accessed: 11.10.2021].

UNESCO Convention on the Means of Prohibiting and Preventing the Illicit Import, Export and Transfer of Ownership of Cultural Property, 14 November 1970, 823 UNTS 231.

UNESCO, International Code of Ethics for Dealers in Cultural Property, 1999, https://unesdoc. unesco.org/ark:/48223/pf0000121320 [accessed: 11.10.2021].

UNIDROIT Convention on Stolen or Illegally Exported Cultural Objects, 24 June 1995, 34 ILM 1322.

United Nations Convention against Transnational Organized Crime and the Protocols Thereto, 15 November 2000, 2225 UNTS 209.

United Nations Security Council, Resolution 661 (1990): Concerning the Situation between Iraq and Kuwait, 6 August 1990, S/RES/661 (1990).

United Nations Security Council, Resolution 1483: The Situation between Iraq and Kuwait, 22 May 2003, S/RES/1483 (2003).

United Nations Security Council, Resolution 2199: Threats to International Peace and Security Caused by Terrorist Acts, 12 February 2015, S/RES/2199 (2015).

United Nations Security Council, Resolution 2347: Maintenance of International Peace and Security, 24 March 2017, S/RES/2347 (2017).

United States of America v One Ancient Mosaic, United States District Court, Central District of California, Western Division, Judgment of 23 March 2018 (18-CV-04420).

Weirich C.A., Antiquities in a Time of Conflict: A Crime Script Analysis of Antiquities Trafficking during the Syrian Civil War and Implications for Conflict Antiquities, "Crime Science" 2021, Vol. 10.

Zarobell J., The Role of Freeports in the Global Art Market, "Artsy", 14 July 2017, https:// www.artsy.net/article/artsy-editorial-freeports-operate-margins-global-art-market [accessed: 30.08.2021].

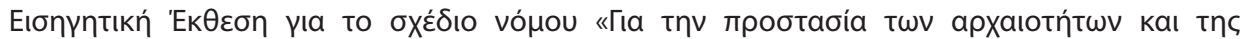
по the Draft Law "On the Protection of Antiquities and Cultural Heritage in General" to the Greek Parliament], 21 May 2002.

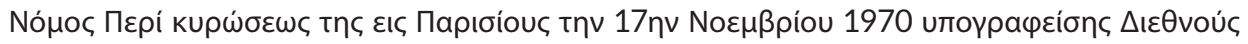

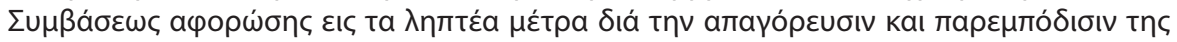

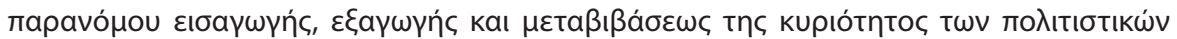

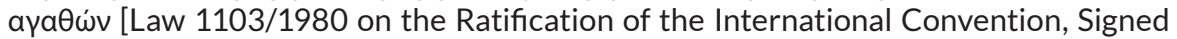
in Paris on 17 November 1970, Concerning Measures to be Taken to Prohibit and Prevent the Illegal Import, Export, and Transfer of Ownership of Cultural Property], Government Gazette A 297/29.12.1980.

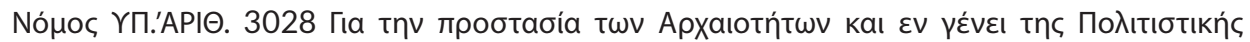
K $\lambda$ npovoulác [Law No. 3028/2002 on the Protection of Antiquities and Cultural Heritage in General], Government Gazette A 153/28.06.2002. 


\section{DEBUTS}

Stella Sarapani

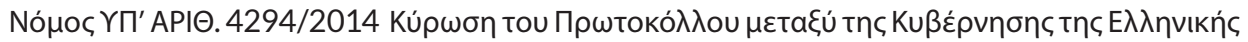

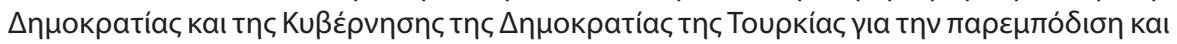

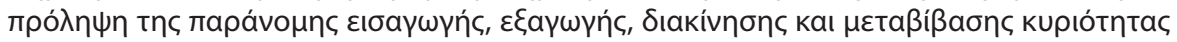

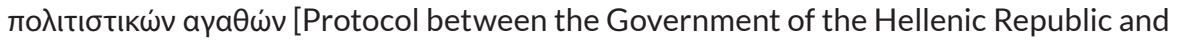
the Government of the Republic of Turkey on the Prohibition and Prevention of the Illicit Import, Export, Transit, and Transfer of Ownership of Cultural Property], Government Gazette A 211/30.09.2014.

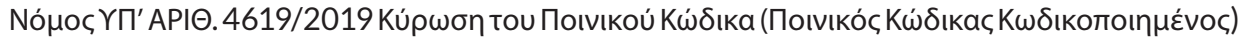
[Ratification of the Penal Code (Codified Penal Code)], Government Gazette A 95/11.06.2019.

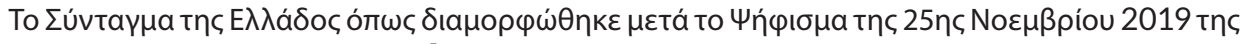

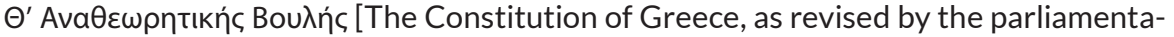
ry resolution of November 25th 2019 of the IX Revisionary Parliament], Government Gazette A 187/28.11.2019. 